Metallophysics and Advanced Technologies Металофіз. новітні технол. Metallofiz. Noveishie Tekhnol. 2019, vol. 41, No. 2, pp. 241-250

https://doi.org/10.15407/mfint.41.02.0241 Reprints available directly from the publisher
(C) 2019 G. V. Kurdyumov Institute for Metal Physics, National Academy of Sciences of Ukraine Published by license under the G. V. Kurdyumov Institute for Metal PhysicsN.A.S. of Ukraine Publishers imprint. Printed in Ukraine.

PACS numbers: 61.72.S-, 61.80.Fe, 81.05.Zx, 81.15.Jj, 81.40.Ef, 81.40.Wx, 81.65.Ps

\title{
Electron-Beam Technology in the Processing of Hafnium Ingots
}

\author{
A. P. Mukhachov and O. A. Kharytonova*
}

Centre of Chemical Technologies of the Academy of Engineering Sciences of Ukraine, 179 Anoshkin Ave., UA-51917 Kamianske, Ukraine

"Dniprovsk State Technical University, 2 Dniprobudivska Str.,

UA-51918 Kamianske, Ukraine

In 1986-1987 in Ukraine, the UE-177RL electron-beam device is tested to process ingots of hafnium with the productivity of 10 tons/year. Wasteless processes of cutting and refining the ingot surface with an electron beam successfully replace cutting the ingot on a planer with a cutter and processing the surface of the hafnium ingot on a lathe. This makes it possible to increase the yield of hafnium from the alloy by $8-12 \%$, depending on the geometry of the ingot, to reduce the amount of chips, to remove the surface defects of the ingot, to obtain a melted layer corresponding to ASTM.

Key words: electron beam, electron gun, ingots of hafnium alloys, cutting, surface melting, chemical composition.

У 1986-1987 рр. в Україні було протестовано електронно-променевий пристрій UE-177RL для оброблення зливків гафнію продуктивністю у 10 тон/рік. Різку зливка стопу на стругальному верстаті за допомогою різця й оброблення поверхні зливка гафнію на токарному верстаті було успішно замінено на безвідходні процеси різання й обтоплення поверхні зливка за допомогою електронного променя. Це уможливлює збільшити вихід гафнію зі стопу на 8-12\%, залежно від геометрії зливка, виключити поверхневі дефекти зливка, одержати обтоплений шар, що відповідає ASTM.

Corresponding author: Anatoliy Petrovych Mukhachov

E-mail: eah@ukr.net

Citation: A. P. Mukhachov and O. A. Kharytonova, Electron-Beam Technology in the Processing of Hafnium Ingots, Metallofiz. Noveishie Tekhnol., 41, No. 2: 241-250 (2019), DOI: 10.15407/mfint.41.02.0241. 
Ключові слова: електронний промінь, електронна гармата, зливки стопів гафнію, різання, обтоплення поверхні, хемічний склад.

В 1986-1987 гг. в Украине электронно-лучевое устройство UE-177RL было протестировано для обработки слитков гафния производительностью 10 тонн/год. Резка слитка сплава на строгальном станке с помощью резца и обработка поверхности слитка гафния на токарном станке были успешно заменены на безотходные процессы резки и оплавления поверхности слитка с помощью электронного луча. Это позволяет увеличить выход гафния из сплава на 8-12\% в зависимости от геометрии слитка, исключить поверхностные дефекты слитка, получить оплавленный слой, соответствующий ASTM.

Ключевые слова: электронный луч, электронная пушка, слитки сплавов гафния, резка, оплавление поверхности, химический состав.

(Received May 10, 2018)

\section{INTRODUCTION}

Metal hafnium in Ukraine is obtained by the method of calciumthermal reduction of its fluoride in the presence of metals that reduce the melting point of hafnium alloys to $1850^{\circ} \mathrm{C}$.

The resulting alloy ingot with a diameter of up to $650 \mathrm{~mm}$ was installed on a planer with a cutter with a width of 10-12 $\mathrm{mm}$. This led to the formation of an oxidized chip of the alloy, the processing of which was possible only by dissolving it in an acid. This operation increased the cost of production.

Due to the high thermal conductivity of hafnium, when the ingot $\varnothing 180 \mathrm{~mm}$ is cooled on the side surface, defects are formed such as corrugations, crusts, shells, etc.

Their occurrence cannot be prevented. The defects in the surface layer were eliminated on a lathe. The use of waste for smelting was impossible due to the high content of oxygen and nitrogen.

Methods for processing the surface of ingots of highly reactive metals, for example titanium, a hafnium analogue with the use of plasma [1], and a laser [2], avoid significant metal losses. The most effective source of heating when processing the surface of ingots of such metals is the electron beam because of a number of known advantages, the presence of vacuum, protective and refining medium, high density of energy input, purity, high quality control and management of technological parameters.

The goal of this work was the development of the design of an electron beam installation with a capacity of up to 10 tons per year, the modernization of its individual units, including systems of electron beam guns, development of a control scheme for them, optimization of 
technological regimes of electron beam cutting and reflow of hafnium ingots as part of the technology.

\section{TECHNIQUE OF INDUSTRIAL EXPERIMENT}

The experiment on cutting hafnium alloy was carried out on an electron-beam furnace UE-177RL [3] (Fig. 1.). The technical characteristics of furnace are given in Table 1.

The furnace consists of a working chamber, a chamber of guns, where electronic guns (PE-101) are placed with a quadrupole lens. The furnace is equipped with a crystallizer, an ingot movement mechanism, a vacuum system, a water cooling system, a high-voltage power supply of an electron-beam heater, and an electron-beam control system.

The working chamber is a horizontal cylinder with an internal diam-

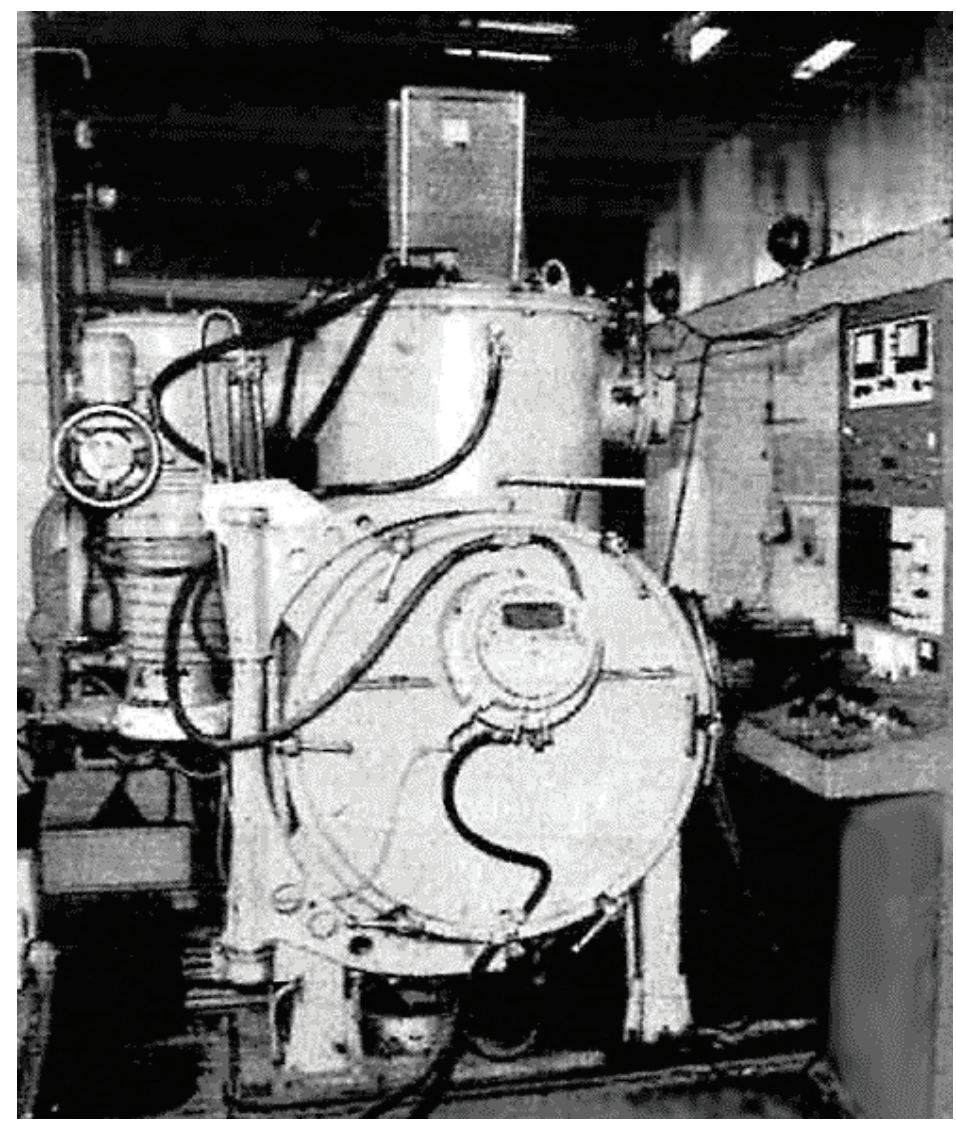

Fig. 1. Electron-beam furnace UE-177RL. 
TABLE 1. Technical characteristics of the UE-177 RL.

\begin{tabular}{lcc}
\hline \multicolumn{1}{c}{ Characteristic } & Dimension & Value \\
\hline Maximum dimensions of the ingot to be cut: & & \\
- diameter & $\mathrm{mm}$ & 650 \\
- height & $\mathrm{mm}$ & 100 \\
Heater power & $\mathrm{kW}$ & 50 \\
Accelerating stress & $\mathrm{kV}$ & 18 \\
Electron beam current & $\mathrm{A}$ & 2.5 \\
Residual gas pressure: & $\mathrm{mmHg}$ & $10^{-4}-10^{-5}$ \\
- in the heater chamber & $\mathrm{mmHg}$ & $10^{-3}-10^{-4}$ \\
- in the working chamber & & \\
Speed of vacuum system evacuation: & $\mathrm{l} / \mathrm{s}$ & 630 \\
- from the heater chamber & $\mathrm{l} / \mathrm{s}$ & 500 \\
- from the working chamber & $\mathrm{m}{ }^{3}$ & 1,0 \\
The volume of the working chamber & $\mathrm{mm} / \mathrm{min}^{\prime}$ & 40 \\
Travel speed of the trolley & & \\
Overall dimensions of the installation: & $\mathrm{mm}$ & 3020 \\
- length & $\mathrm{mm}$ & 1350 \\
- width & $\mathrm{mm}$ & 2100 \\
- height & $\mathrm{hour}$ & 1,0 \\
Preparatory cycle time & $\mathrm{kW} / \mathrm{cm}^{2}$ & $6,0-8,0$ \\
Specific beam power & &
\end{tabular}

eter of $850 \mathrm{~mm}$, cooled by water. The manhole is designed to load the alloy. The inspection system is mounted on it. The second hatch has a clamping device and is used as a safety valve. This allows increasing the safety of furnace in emergencies associated with a sudden increase in pressure in the working chamber. The ingot moves on the trolley with a drive. It allows you to move reversely the trolley along the axis of the camera.

A container for collecting metal discharged from the cutting zone by an electron beam represents a copper water-cooled mould made in the form of a boat.

The mould has dimensions of $440 \times 100 \times 90 \mathrm{~mm}^{3}$. Two flat-beam electron guns of the PE-101 type with electrostatic and electromagnetic focusing of the electron beam are placed in the heater chamber.

Electrostatic focusing of the beam is carried out due to the shape and mutual location of the anode and cathode. Electromagnetic focusing is realized with the help of a quadrupole lens placed behind the anode.

The vacuum system of the plant consists of a high-vacuum pump H250/630, a two-rotor RPV $1800 \mathrm{Sp} 2$ and a forevacuum A2 DS 150 pump.

The cutting of the ingot is carried out by moving the workpiece on a trolley under two stationary electron beams. The focal spot of the beam on the slit ingot takes the form of a strip 2-3 mm wide and 180-200 
mm long.

This allows achieving a power concentration on the surface of the alloy $6.0-8.5 \mathrm{~kW} / \mathrm{cm}^{2}$ and producing a cutting width not exceeding 12 $\mathrm{mm}$.

Metal on the inclined surface of the cut merges into the crystallizer, where the ingot is formed. The process of cutting the alloy with an electron beam makes it possible to melt the limited sections of the ingot and to remove metal without loss from the cutting zone [4].

At the meeting place of the electron beam with the surface of the ingot, a bath with a melt appears, its depth depends on the specific power of the beam, which is $6.0-8.5 \mathrm{~kW} / \mathrm{cm}^{2}$.

Constant removal of molten metal and movement of the ingot to be cut allow the cutting width to be kept similar to that of the mechanical cutting.

Removal of alloying metals, iron, and aluminium was carried out in an electron-beam furnace of the UE-178M type (Fig. 2). Because of a three-time remelting, a hafnium ingot $\varnothing 180 \mathrm{~mm}$ was obtained, weighing $80-100 \mathrm{~kg}$.

Requirements for ingots for processing their pressure, do not allow

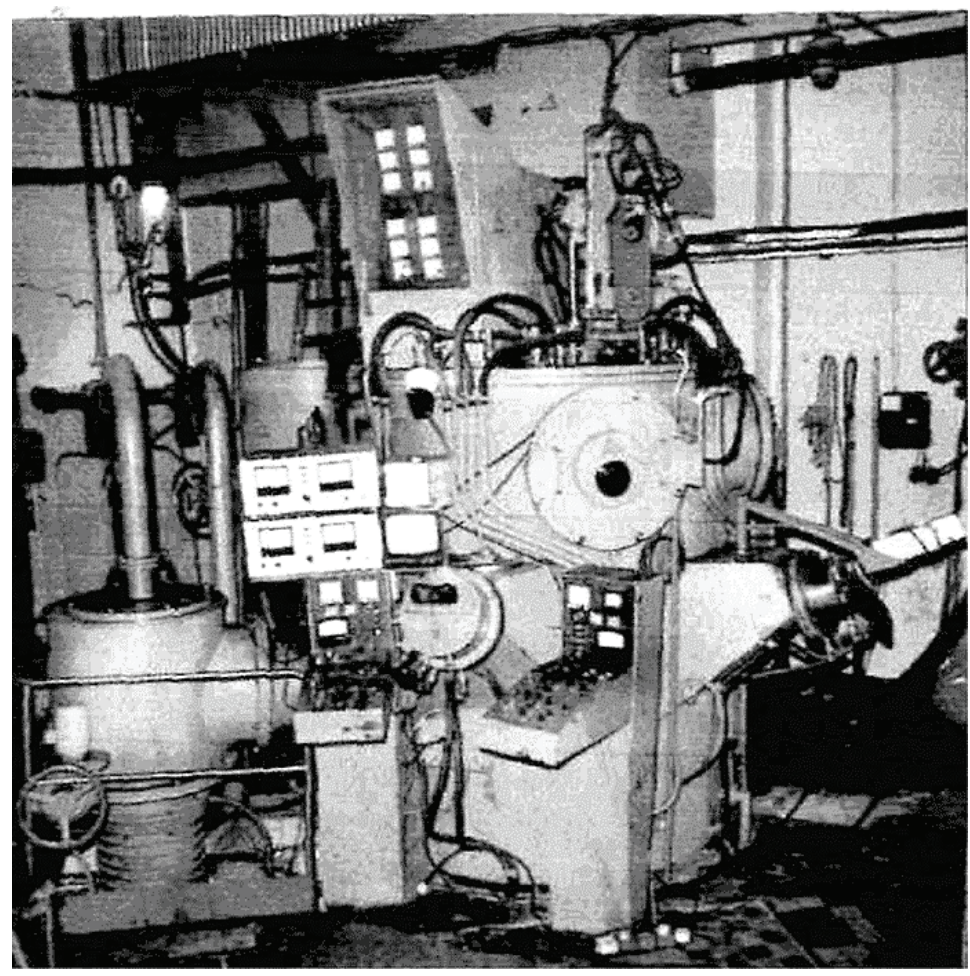

Fig. 2. Electron-beam furnace UE-178M. 


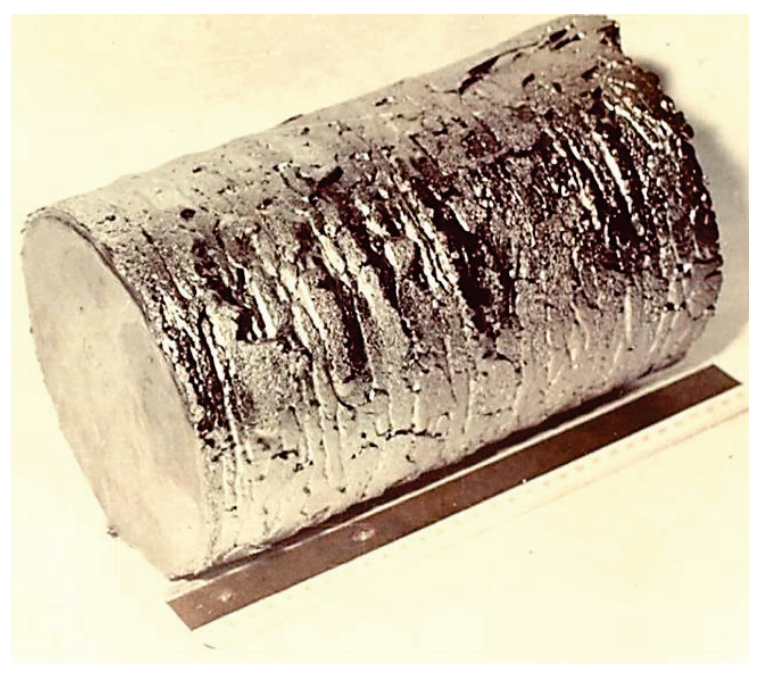

Fig. 3. Hafnium stitch.

surface defects. This condition causes the need for turning roughing of the defective layer.

To improve the quality of the surface of the hafnium ingot, an electron gun was used, which allows fusion to be carried out by a planar or linearly developed beam with a focal spot stretched over the length of the ingot (Fig. 3).

Based on the analysis, a fundamentally new process for melting hafnium ingots was proposed.

It consisted of exposing the surface of an ingot to an electron beam having modulated frequency components of focal spot scan in the range $50-300 \mathrm{~Hz}$ and $2-10 \mathrm{~Hz}$. The power of first frequency component is in the range of $60-70 \%$ of the total beam power [5].

The ingot was placed in the chamber on the rollers.

After sealing and evacuating the chamber to a residual pressure of $5 \cdot 10^{-3}-1 \cdot 10^{-4} \mathrm{mmHg}$ included an electron beam. Using the horizontal sweep, the required beam length was formed and the ingot rotation was turned on.

The specific power of the electron beam to the required value was increased by including a block of programmable scans.

\section{RESULT AND DISCUSSION}

The blanks for electron-beam refining were segments of the hafniumiron-aluminium alloy with a width of no more than $220 \mathrm{~mm}$ with a length of up to $650 \mathrm{~mm}$. The mass of the billet did not exceed $120 \mathrm{~kg}$. The cutting speed of the ingot by the beam was $40 \mathrm{~mm} / \mathrm{min}, 1$ cutting 
of the cutting required 15-20 min of the beam, two seams $-30-40$ min. It is more productive than cutting with a tool.

The mass of the condensate and the metal spray during cutting do not exceed $0.1 \%$ by weight. The share of metal from the cutting zone and processed into the casting is $3.6-4.8 \%$ of the mass of the ingot being processed. The results of the chemical analysis showed that the content of oxygen, nitrogen, iron, chromium, nickel, aluminium in ingots before and after cutting remains unchanged. The cutting speed of the ingot provided continuous operation of the UE-178M electron beam device.

The first high-frequency component of the scan $50-300 \mathrm{~Hz}$ supports the metal, in the zone of linear scanning, heated and compensates for the thermal losses by thermal conductivity and radiation. The second frequency component of the sweep evenly melts the metal to the required depth.

When using the first frequency component of less than $50 \mathrm{~Hz}$, the effect of scanning the electron beam in two coordinates appears and it is possible to observe on the surface of the ingot the appearance of two energy concentration zones moving relative to each other. This leads to uneven penetration of the ingot surface in the places where the zones are deposited. The width of the melted zone of the ingot at a beam current of $1-1.5 \mathrm{~A}$ is $10-15 \mathrm{~mm}$; the length of the linear sweep is up to 400 $\mathrm{m}$ (corresponding to the length of the melted ingot). The linear reflow rate is $30-50 \mathrm{~mm} / \mathrm{min}$.

Melting of the side surface of a hafnium ingot with a linear electron beam with two frequency components of the sweep makes it possible to melt the metal to a depth of 7-10 $\mathrm{mm}$ and to obtain a defect-free surface layer of the same depth (Fig. 4).

As a result of experiments, it was established that the optimum specific power of first modulated frequency is $60-70 \%$ of the total beam power. This makes it possible to achieve an even depth of penetration of the surface layer along the entire length of the ingot.

With a decrease in the power of first frequency component of less than $60 \%$, an uneven melted surface begins to form.

With an increase in the power fraction of first frequency, which is more than $70 \%$ of the total beam power, the melting depth along the length of the ingot is uneven.

The ingot after melting did not have surface defects; its surface was uniformly smooth, shiny.

Analysis of the chemical composition of fused ingots of hafnium showed that they correspond to the technical conditions for the content of impurities.

In order to study the structure of the metal, the templates at different distances from the surface of the ingot to determine the hardness were cut out at the depth of the ingot penetration in the fusion zone. 


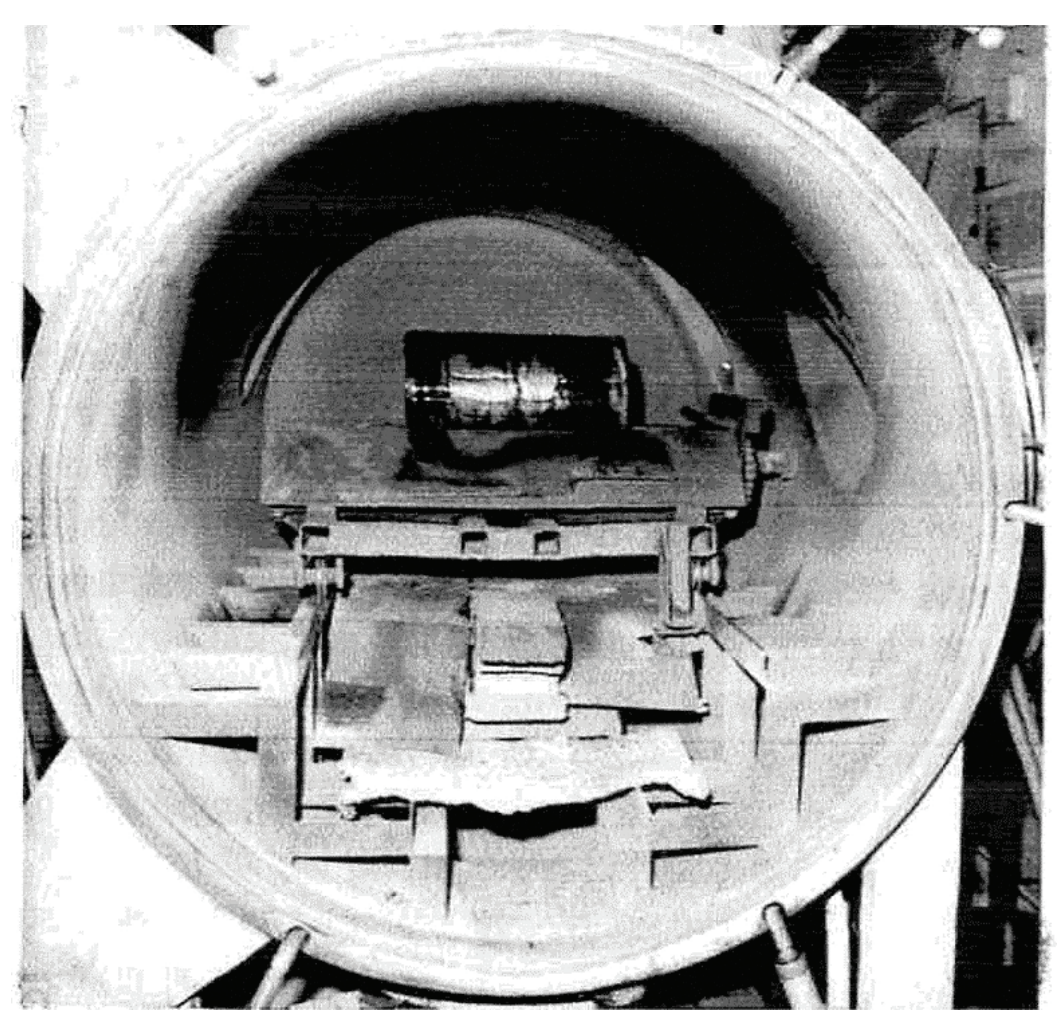

Fig. 4. Hafnium ingot after treatment with a ray.

The results are shown in Table 2.

As follows from the data given, the hardness values have a small variation in depth in the range of $1-2 \%$, which indicates the uniform structure of fused layer. The depth of the melted layer does not vary along the length of the ingot.

The yield of metal in the ingot at the reflow operation was $99.8 \%$ by weight.

The reflowing technology of the lateral surface of hafnium ingots according to the proposed mechanism made it possible to obtain ingots with a high surface quality, suitable for pressure treatment.

Thus, the use of an electron beam for cutting and melting an ingot of hafnium showed high economic and technological efficiency. The new technology has allowed increasing labour productivity, to reduce losses of metal at high quality.

\section{CONCLUSIONS}

1. Electron-beam unit UE-177RL showed its efficiency. It allowed de- 
TABLE 2. Results of measuring the hardness of fused ingots of hafnium.

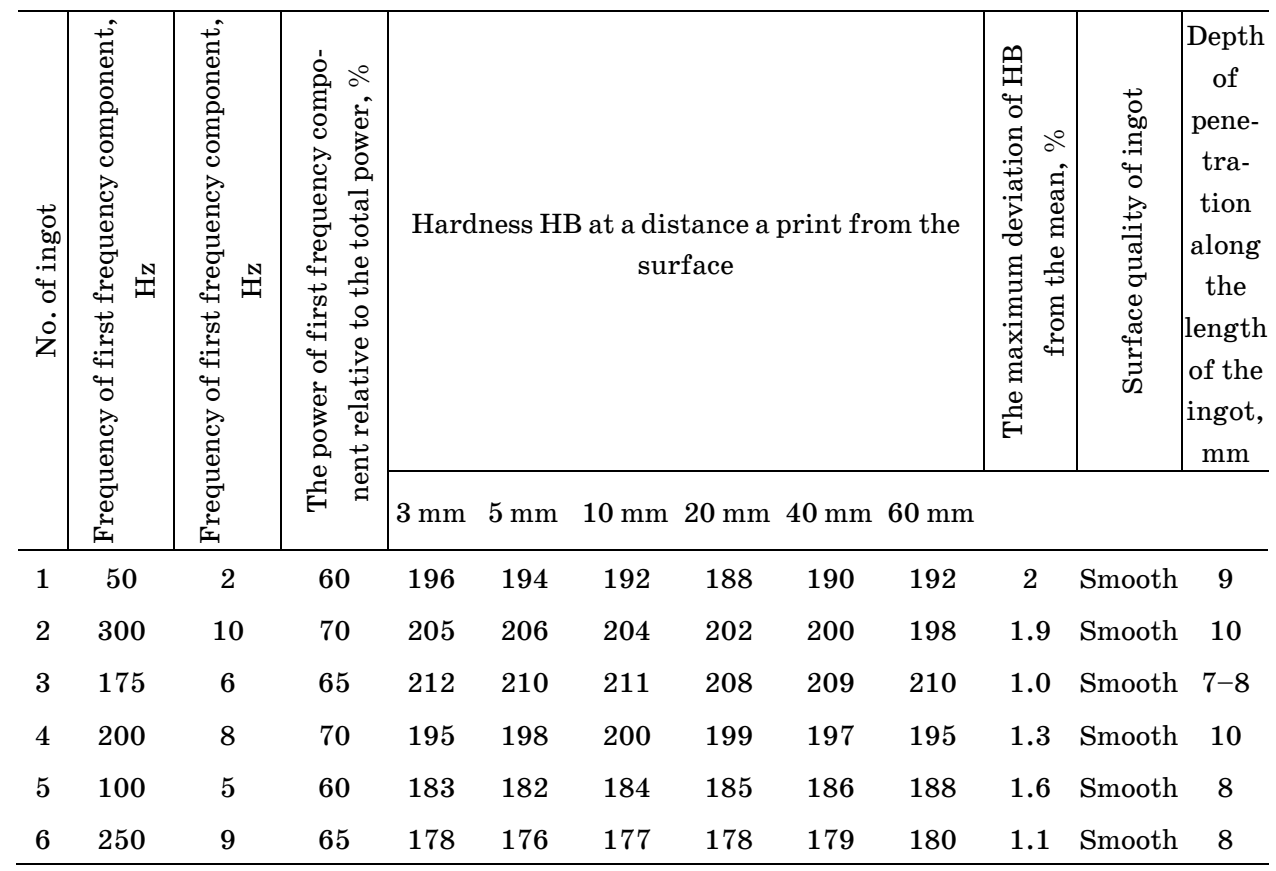

veloping an industrial technology for cutting hafnium alloy and melting the cylindrical surface of its ingot, which reduced the yield of expensive metal in chips from $16 \%$ to $5 \%$.

2 . The content of metallic impurities before and after cutting and melting remains unchanged.

3. The ingot obtained after melting is ready for deformation.

4. The selected technical and technological solutions ensured the productivity of the metallurgical conversion of hafnium to 10 tons per year.

\section{REFERENCES}

1. Yu. L. Latash, G. F Torkhov, Yu. I. Modelkin et al., Problemy Spetselektrometallurgii, Iss. 18: 75 (1983) (in Russian).

2. Yu. M. Pomarin, V. Yu. Orlovskiy, B. N. Medovar et al., Problemy Spetselektrometallurgii, No. 2: 102 (1992) (in Russian).

3. K. N. Klyuev, S. L. Tulubtsov, S. A. Shershnev et al., Sposob Elektronno-Luchevoy Rezki Metallov i Splavov (Copyright Certificate USSR No. 1210327 16.02.84).

4. Yu. F. Zavgorodniy, K. N. Klyuev, B. A. Movchan et al., Elektronnaya Pushka dlya Elektronno-Luchevogo Pereplava (Copyright Certificate USSR No. 1360490 22.10.85). 
5. B. A. Movchan, V. A. Timashov, and K. N. Klyuev, Ustanovka dlya Elektronno-Luchevogo Nagreva Metallov (Copyright Certificate USSR No. 705699, 25.12.79 BI No. 47).

6. S. V. Anokhin, V. A. Verezos, A. N. Pikulin et al., Problemy Spetselektrometallurgii, No. 2: 21 (2014) (in Russian).

7. N. P. Trigub, G. V. Zhuk, A. N. Pikulin et al., Sovremennaya Elektrometallurgiya, No. 2: 102 (2003) (in Ukrainian). 